Thomas C. Kwee Robert M. Kwee

\section{Combined FDG-PET/CT for the detection of unknown primary tumors: systematic review and meta-analysis}

Received: 23 April 2008

Revised: 11 August 2008

Accepted: 5 September 2008

Published online: 17 October 2008

(C) The Author(s) 2008
T. C. Kwee $(\bowtie)$

Department of Radiology,

University Medical Center Utrecht,

Heidelberglaan 100,

3584 CX Utrecht, The Netherlands

e-mail: thomaskwee@gmail.com

Tel.: +31-88-7556687

Fax: $+31-30-2581098$

\section{R. M. Kwee}

Department of Radiology,

University Medical Center Maastricht, Maastricht, The Netherlands

\begin{abstract}
The aim of this study was to systematically review and meta-analyze published data on the diagnostic performance of combined 18F-fluoro2-deoxyglucose positron emission tomography/computed tomography (FDG-PET/CT) in the detection of primary tumors in patients with cancer of unknown primary (CUP). A systematic search for relevant studies was performed of the PubMed/MEDLINE and Embase databases. Methodological quality of the included studies was assessed. Reported detection rates, sensitivities and specificities were metaanalyzed. Subgroup analyses were performed if results of individual studies were heterogeneous. The 11 included studies, comprising a total sample size of 433 patients with CUP, had moderate methodological quality. Overall primary tumor detection rate, pooled sensitivity and specificity of FDG-PET/CT were $37 \%, 84 \%$ (95\% CI $78-88 \%$ ) and $84 \%$ (95\% CI 78-89\%),
\end{abstract}

respectively. Sensitivity was heterogeneous across studies $(\mathrm{P}=0.0001)$, whereas specificity was homogeneous across studies $(\mathrm{P}=0.2114)$. Completeness of diagnostic workup before FDG-PET/CT, location of metastases of unknown primary, administration of $\mathrm{CT}$ contrast agents, type of FDG-PET/CT images evaluated and way of FDG-PET/CT review did not significantly influence diagnostic performance. In conclusion, FDG-PET/CT can be a useful method for unknown primary tumor detection. Future studies are required to prove the assumed advantage of FDG-PET/CT over FDG-PET alone and to further explore causes of heterogeneity.

\section{Keywords FDG-PET/CT .}

Cancer of unknown primary .

Primary tumor detection .

Systematic review .

Meta-analysis

\section{Introduction}

Cancer of unknown primary (CUP), defined as the presence of histologically proven metastatic disease for which the site of origin cannot be identified at the time of diagnosis (despite comprehensive diagnostic workup), is one of the ten most frequent cancers (accounting for 3-5\% of all malignancies) and is the fourth most common cause of cancer-related death $[1,2]$. Failure to detect the primary tumor impedes optimization of treatment planning, which, in turn, may negatively influence patient prognosis. ${ }^{18} \mathrm{~F}$ fluoro-2-deoxyglucose positron emission tomography
(FDG-PET) allows whole-body tumor detection [3] and has proven to be useful in patients with CUP for the detection of the primary tumor [4-6]. A disadvantage of FDG-PET, however, is its lack of anatomic information, which may impede precise localization of FDG accumulation. Furthermore, tumors with low or even no FDG uptake may be missed by FDG-PET. Complimentary anatomic information, provided by computed tomography (CT) or magnetic resonance (MR) imaging, may improve the diagnostic performance of FDG-PET alone. The relatively recently introduced combined FDG-PET/CT scanner allows obtaining both functional and anatomic images in 
a single examination $[7,8]$ and may be of great value for the detection of primary tumors in patients with CUP. The purpose of this study was therefore to systematically review and meta-analyze published data on the diagnostic performance of FDG-PET/CT in unknown primary tumor detection.

\section{Methods}

Search strategy

A computer-aided search of the PubMed/MEDLINE and Embase databases was conducted to find relevant published articles on the diagnostic performance of combined FDG-PET/CT in primary tumor detection in patients with CUP. The search strategy is presented in Table 1 . No beginning date limit was used. The search was updated until 13 March 2008. Only English-, German-, French-, Italian- or Spanish-language studies were considered because the investigators were familiar with these languages. To expand our search, bibliographies of articles that finally remained after the selection process were screened for potentially suitable references.

\section{Study selection}

Studies or subsets in studies investigating the diagnostic performance of FDG-PET/CT in primary tumor detection in patients with CUP were eligible for inclusion. Review articles, meta-analyses, abstracts, editorials or letters, case reports, guidelines for management and studies examining ten or fewer patients with CUP were excluded. Studies or subsets in studies were excluded if metastases were not histologically confirmed. Studies that provided insufficient data to construct a $2 \times 2$ contingency table to calculate sensitivity and specificity for primary tumor detection in patients with CUP were also excluded. When data were presented in more than one article, the article with the largest number of patients or the article with the most details was chosen.
Two researchers (T.C.K., R.M.K.) independently reviewed the titles and abstracts of the retrieved articles, applying the inclusion and exclusion criteria mentioned above. Articles were rejected if they were clearly ineligible. The same two researchers then independently reviewed the full-text version of the remaining articles to determine their eligibility for inclusion. Disagreements were resolved in a consensus meeting.

Data abstraction

For each included study, information was collected concerning basic study and patient characteristics (author names, year of publication, country of origin, study design, number, age and sex ratio of investigated patients, location of metastases of unknown primary, histology of metastases of unknown primary and diagnostic workup before FDGPET/CT), FDG-PET/CT parameters (time of fasting before FDG administration, FDG dose, time interval between FDG administration and data acquisition, number of CT detector rows, reconstructed CT slice width, administration of intravenous and/or oral CT contrast agents and area of body examined) and FDG-PET/CT evaluation (evaluation of attenuation-corrected and/or non-attenuation corrected images, interpreters(s) of FDG-PET/CT, criteria for positivity and applied reference standard).

To calculate estimates of diagnostic performance (i.e., primary tumor detection rate, sensitivity and specificity), a true-positive result was considered when FDG-PET/CT suggested the location of the primary tumor and was subsequently confirmed. A false-positive result was considered when this location was not confirmed. The sites suggested by FDG-PET/CT were confirmed by histopathological analysis of tissue obtained by biopsy or surgery, considered as the reference standard. However, imaging procedures or clinical follow-up was accepted if no histopathological proof could be obtained. A truenegative result was considered when neither FDG-PET/CT nor the reference standard could detect the primary tumor. A false-negative result was considered if the primary tumor was detected in a particular location that was negative on FDG-PET/CT $[4,6]$.

Table 1 Search strategy and results as on 13 March 2008

\begin{tabular}{|c|c|c|c|}
\hline \# & Search string & $\begin{array}{l}\text { PubMed/ } \\
\text { MEDLINE }\end{array}$ & Embase \\
\hline 1 & $\begin{array}{l}\text { Fluorodeoxyglucose OR 2-fluoro-2-deoxy-D-glucose OR FDG OR positron emission tomography } \\
\text { OR positron-emission tomography OR PET }\end{array}$ & 39,616 & 46,549 \\
\hline 2 & Computed tomography OR computerized tomography OR computed tomographic OR CT OR CAT & 430,940 & 317,859 \\
\hline 3 & Unknown primary OR unidentified primary OR occult primary OR unknown origin OR unidentified origin & 32,203 & 25,105 \\
\hline 4 & $\# 1$ AND \#2 AND \#3 & 230 & 185 \\
\hline
\end{tabular}


Study quality

For each included study, the methodological quality was assessed by using the Quality Assessment of Studies of Diagnostic Accuracy Included in Systematic Reviews (QUADAS) criteria, which is a 14-item instrument [9, 10]. The item "Is the time period between reference standard and index test short enough to be reasonably sure that the target condition did not change between the two tests?" was removed from the standard
QUADAS list, since follow-up is required to verify negative FDG-PET/CT findings. The item "Did patients receive the same reference standard regardless of the index test result?" was removed from the standard QUADAS list, since positive FDG-PET/CT findings can be confirmed by means of histology, but negative FDG-PET/CT findings require follow-up. The item "Were the reference standard results interpreted without knowledge of the results of the index test?" was also removed from the standard QUADAS list, since

Table 2 Criteria list used to assess the methodological quality of the studies

Quality item Positive score

Was the spectrum of patients representative of the patients who will Patients with histologically confirmed metastatic cancer, in whom receive the test in practice? medical history, physical examination, full blood count, basic biochemistry battery, urinalysis, stool occult blood testing, immunohistochemistry with specific markers as well as imaging technology with chest X-ray, computed tomography of the chest abdomen and pelvis or mammography and MR imaging in certain cases failed to detect the primary tumor, were included

Were selection criteria clearly described?

Is the reference standard likely to correctly classify the target condition?

It was clear how patients were selected for inclusion

Histopathological analysis of tissue obtained by biopsy or surgery, or imaging procedures or clinical follow-up if no histopathological proof could be obtained

Did the whole sample, or a random selection of the sample, receive All patients, or a random sample of patients who underwent FDG-PET/ verification using a reference standard of diagnosis?

$\mathrm{CT}$, also underwent the reference standard

Was the reference standard independent of the index test (i.e., the FDG-PET/CT did not form part of the reference standard index test did not form part of the reference standard)?

Was the execution of the index test described in sufficient detail to All of the following parameters were described: permit replication of the test?

-Time of fasting before FDG administration, FDG dose, time interval between FDG administration and scanning

-Application of intravenous and/or oral CT contrast

-Scanned area

-Evaluated images (AC and/or nAC)

-Interpreter(s) of FDG-PET/CT mentioned

Was the execution of the reference standard described in sufficient Besides histopathological analysis of FDG-PET/CT positive findings, detail to permit replication? additional diagnostic procedures (e.g., gastroscopy, CT, MR imaging) and duration of follow-up were described, if applicable

Were the index test results interpreted without knowledge of the results of the reference standard?

Were the same clinical data available when test results were interpreted as would be available when the test is used in practice?

Were uninterpretable/intermediate test results reported?

Were withdrawals from the study explained?

Was comparator review bias avoided?

FDG-PET/CT was interpreted without knowledge of the findings of the reference standard

Interpreter(s) of FDG-PET/CT was/were aware of the histologic nature of the metastases of unknown primary

All FDG-PET/CT results, including uninterpretable/ indeterminate/ intermediate were reported

It is clear what happened to all patients who entered the study

Blinding FDG-PET/CT to the other imaging modality, if more than one imaging modality was applied

AC: attenuation-corrected images

nAC: non-attenuation-corrected images

CT: computed tomography

FDG-PET: ${ }^{18}$ F-fluoro-2-deoxyglucose

FDG-PET/CT: ${ }^{18}$ F-fluoro-2-deoxyglucose positron emission tomography/computed tomography

MR: magnetic resonance 
positive FDG-PET/CT findings can be verified by means of histopathological analysis of tissue obtained by biopsy or surgery. One item was added to the standard QUADAS list: "Was comparator review bias avoided?" The complete list of quality items is displayed in Table 2. For each item, the two researchers (TCK, RMK) independently assessed whether it was fulfilled (yes or no). If it was unclear from the information provided in an article as to whether an item was fulfilled, the item was rated as "unclear." Both "no" and "unclear" responses were interpreted as indicating that the quality criterion was not met. Disagreements were discussed and resolved by consensus. The total quality score was expressed as a percentage of the maximum score of 12 .

\section{Statistical analysis}

Primary tumor detection rates of individual studies were calculated and totaled. Locations of primary tumors detected by FDG-PET/CT, locations of false-positives FDG-PET/CT findings and locations of false-negative FDG-PET/CT findings were recorded and summarized. Sensitivities and specificities of FDG-PET/CT in primary tumor detection (with corresponding 95\% CIs) were calculated from the original numbers given in the included studies and meta-analyzed using a random effects model. Where sensitivity or specificity estimates for an individual study were zero, a continuity correction of 0.5 was added to every value for that study in order to make the calculation of sensitivity and specificity defined.

A chi-squared test was performed to test for heterogeneity between studies. Heterogeneity was defined as $\mathrm{P}<$ 0.10 . Differences in sensitivities and specificities due to different cut-offs (thresholds) used in different studies to define a positive (or negative) FDG-PET/CT results were assessed by computing the Spearman correlation coefficient between the logit of sensitivity and logit of 1-specificity. A strong positive correlation would suggest the presence of a threshold effect. Other potential sources for heterogeneity were explored by assessing whether certain predefined covariates significantly influenced (i.e., $\mathrm{P}<0.05$ ) the relative diagnostic odds ratio (RDOR) [11]. Although the findings of such analyses should be regarded mainly as hypothesis generating, statistical significance may suggest substantial changes in the diagnostic performance of the test under study as the covariate changes. Specifically, analyses were performed according to completeness of diagnostic workup before FDG-PET/CT (studies that fulfilled quality item 1 vs. studies that did not fulfill quality item 1 [Table 2]), location of metastases of unknown primary (cervical vs. extracervical), administration of CT contrast agents (both intravenous and oral contrast vs. no intravenous or oral contrast agent, or not reported), type of FDGPET/CT images evaluated (both attenuation-corrected and non-attenuation-corrected images vs. attenuation-corrected images only, or not reported) and way of FDG-PET/CT review (reported blinding to reference test vs. no or unreported blinding to reference test.

Statistical analyses were executed using the Statistical Package for the Social Sciences version 14.0 software (SPSS Inc., Chicago, IL) and Meta-DiSc statistical software version 1.4 (Unit of Clinical Biostatistics, Ramón y Cajal Hospital, Madrid, Spain) [11].

\section{Results}

Literature search

The computer-aided search revealed 230 articles from PubMed/MEDLINE and 185 articles from Embase (Table 1). Reviewing titles and abstracts from PubMed/ MEDLINE revealed 17 articles potentially eligible for inclusion. Reviewing titles and abstracts from Embase

Table 3 Basic study and patient characteristics (1)

\begin{tabular}{|c|c|c|c|c|c|}
\hline Study and year & Country of origin & Study design & No. of patients & Age in years (mean, range) & $\operatorname{Sex}(M / F)$ \\
\hline Fencl et al. [12], 2007 & Czech Republic & Retrospective & 82 & NR & NR \\
\hline Nassenstein et al. [13], 2007 & Germany & NR & 39 & $60,39-89$ & $31 / 8$ \\
\hline Fleming et al. [14], 2007 & USA & Retrospective & 22 & NR & NR \\
\hline Bruna et al. [15], 2007 & France & Retrospective & 37 & $59,31-85$ & $14 / 23$ \\
\hline Wartski et al. [16], 2007 & France & Retrospective & 38 & $57,36-80$ & $31 / 7$ \\
\hline Ambrosini et al. [18], 2006 & Italy & NR & 38 & $59,41-77$ & $22 / 16$ \\
\hline Fakhry et al. [20] 2006 & France & Retrospective & 22 & $48,43-71$ & $17 / 5$ \\
\hline Pelosi et al. [22], 2006 & Italy & Retrospective & 68 & $63,42-79$ & $36 / 32$ \\
\hline Nanni et al. [26], 2005 & Italy & NR & 21 & $60,41-87$ & $12 / 9$ \\
\hline Freudenberg et al. [27], 2005 & Germany & Retrospective & 21 & $64,46-94$ & $16 / 5$ \\
\hline Gutzeit et al. [29], 2005 & Germany & Retrospective & 45 & $57,29-95$ & $26 / 19$ \\
\hline
\end{tabular}

NR: not reported 
Table 4 Basic study and patient characteristics (2)

\begin{tabular}{lll}
\hline Study and year & $\begin{array}{l}\text { Location of metastases of Histology of metastases of } \\
\text { unknown primary }(\mathrm{N})\end{array}$ & Diagnostic workup before FDG-PET/CT \\
& &
\end{tabular}

$\begin{array}{ll}\text { Fencl et al. [12], } 2007 & \text {-Cervical (20) } \\ & \text {-Extracervical (61) }\end{array}$

Nassenstein et al. [13], 2007 Cervical (39)

Fleming et al. [14], 2007

Bruna et al. [15], 2007

Wartski et al. [16], 2007

Cervical (38)

Ambrosini et al. [18], 2006
Cervical and extracervical (22)

Cervical and extracervical (37)
-Anaplastic carcinoma (35)

-Adenocarcinoma (24)

-Squamous-cell carcinoma (5)

-Spinocellular carcinoma (7)

-Mucinous carcinoma (10)

-Small-cell carcinoma (1)

-Squamous-cell carcinoma (27)

-Adenocarcinoma (5)

-Undifferentiated carcinoma (2)

-Lymphoepithelioid cancer (1)

-Malignant melanoma (1)

-Neuroendocrine cancer (1)

-Papillary carcinoma (1)

-Undifferentiated carcinoma (1)

NR

-Adenocarcinoma (17)

-Squamous-cell carcinoma (14)

- Undifferentiated carcinoma (6)
In all patients detailed medical history, full physical and laboratory examinations and diagnostic imaging methods

In all patients tumor workup including physical examination, ultrasound, chest $\mathrm{X}$-ray as well as complete endoscopic exploration with multiple blind biopsies of the nasopharynx, tonsils and tongue base

NR

In all but three patients, CT of the neck and thorax; the three patients without a $\mathrm{CT}$ of the neck and thorax had at least a chest X-ray. In all patients CT and/or ultrasound of the abdomen and pelvis. In $13 / 23$ females mammography and ultrasound of the breasts, in five females an additional MR of the breasts. In 25 patients, invasive diagnostic tests (endoscopic or surgical), of which 16 were bronchoscopies, 10 upper airway endoscopies, 9 colonoscopies and 8 gastroscopies

-Squamous-cell carcinoma (32) -Undifferentiated carcinoma (4) -Mucoepidermoid carcinoma (2)

In all patients systematic palpation, fiber-optic laryngoscopy and nasopharyngoscopy, CT and/or MR imaging with sections from the skull base to the mediastinum and rigid panendoscopy with randomized biopsies at the most frequent sites of primary tumor

In all patients physical examination and negative laboratory and imaging tests; all patients underwent multislice CT and MR imaging
-Epithelial carcinoma (8)

-Squamous-cell carcinoma (5)

-Mucoid adenocarcinoma (2)

-Poorly differentiated carcinoma (2)

-Undifferentiated

adenocarcinoma (2)

-Flat-cell tumor (1)

-Germ-cell tumor (1)

-Melanoma (1)

-Spindle-cell tumor (1)

-Spinous-cell carcinoma (1)

-Transitional-cell carcinoma (1) 
Table 4 (continued)

\begin{tabular}{|c|c|c|c|}
\hline Study and year & $\begin{array}{l}\text { Location of metastases of } \\
\text { unknown primary }(\mathrm{N})\end{array}$ & $\begin{array}{l}\text { Histology of metastases of } \\
\text { unknown primary }(\mathrm{N})\end{array}$ & Diagnostic workup before FDG-PET/CT \\
\hline Fakhry et al. [20] 2006 & -Cervical (22) & -Squamous-cell carcinoma (22) & In all patients $\mathrm{CT}$ and nasofibroscopy \\
\hline Pelosi et al. [22], 2006 & $\begin{array}{l}\text {-Cervical (18) } \\
\text {-Extracervical (50) }\end{array}$ & $\begin{array}{l}\text {-Undefined carcinoma (32) } \\
\text {-Adenocarcinoma (18) } \\
\text {-Squamous-cell carcinoma (8) } \\
\text {-Poorly differentiated carcinoma (5) } \\
\text {-Melanoma (4) } \\
\text {-Urothelial-cell carcinoma (1) }\end{array}$ & $\begin{array}{l}\text { In all patients physical examination, } \\
\text { laboratory tests and conventional } \\
\text { diagnostic procedures, i.e., chest } \\
\text { X-ray, abdominal contrast } \\
\text { enhancement CT and, on the basis } \\
\text { of suspected primary disease, } \\
\text { chest contrast enhancement CT, } \\
\text { MR imaging, ultrasonography, } \\
\text { mammography and endoscopic } \\
\text { procedures }\end{array}$ \\
\hline Nanni et al. [26], 2005 & $\begin{array}{l}\text {-Cervical (3) } \\
\text {-Extracervical (17) } \\
\text {-Cervical and } \\
\text { extracervical (1) }\end{array}$ & $\begin{array}{l}\text {-Adenocarcinoma (8) } \\
\text {-Squamous-cell carcinoma (7) } \\
\text {-Poorly differentiated carcinoma (1) } \\
\text {-Melanoma (1) } \\
\text {-Transitional-cell carcinoma (1) } \\
\text {-Germ-cell tumor (1) } \\
\text {-Spindle-cell carcinoma (1) } \\
\text {-Flat-cell tumor (1) }\end{array}$ & $\begin{array}{l}\text { In all patients physical examination } \\
\text { (digital rectal examination with tests } \\
\text { for occult blood in the stool, breast } \\
\text { palpation and pelvic examination } \\
\text { in women, prostate and testicular } \\
\text { examination in men) and traditional } \\
\text { diagnostic procedures according to } \\
\text { international guidelines (complete } \\
\text { blood counts, liver and renal function } \\
\text { tests, urine analysis, chest radiography, } \\
\text { CT and/or MRI of the abdomen and } \\
\text { pelvis plus X-ray mammography in } \\
\text { women and prostate-specific antigen } \\
\text { test in men) }\end{array}$ \\
\hline Freudenberg et al. [27], 2005 & Cervical (21) & $\begin{array}{l}\text {-Squamous-cell carcinoma (14) } \\
\text {-Adenocarcinoma (4) } \\
\text {-Undifferentiated malignancy (3) }\end{array}$ & $\begin{array}{l}\text { In all patients clinical, endoscopic, } \\
\text { sonographic and planar radiological } \\
\text { staging (none of the patients had } \\
\text { received a dedicated head and } \\
\text { neck CT before) }\end{array}$ \\
\hline Gutzeit et al. [29], 2005 & $\begin{array}{l}\text {-Cervical (18) } \\
\text {-Extracervical (27) }\end{array}$ & $\begin{array}{l}\text {-Adenocarcinoma (25) } \\
\text {-Squamous-cell carcinoma (15) } \\
\text {-Undifferentiated carcinoma (5) }\end{array}$ & $\begin{array}{l}\text { In all patients a complete medical history, } \\
\text { thorough physical examination and } \\
\text { conventional diagnostic strategies } \\
\text { (including comprehensive laboratory } \\
\text { analysis, projectional and cross-sectional } \\
\text { imaging and endoscopic procedures } \\
\text { where indicated) }\end{array}$ \\
\hline
\end{tabular}

CT: computer tomography

FDG-PET/CT: ${ }^{18}$ F-fluoro-2-deoxyglucose positron emission tomography/computed tomography

MR: magnetic resonance

NR: not reported

revealed 17 articles potentially eligible for inclusion, of which 15 were all already identified by the PubMed/ MEDLINE search. Thus, 19 studies [12-30] remained for possible inclusion and were retrieved in full text version. Screening of the references of these 19 articles did not bring up new articles. After reviewing the full article, two articles $[17,19]$ were excluded because a part of the study population underwent FDG-PET alone and was not separately analyzed from patients undergoing FDG-PET/CT, two articles [25, 30] were excluded because sensitivity and specificity for primary tumor detection could not be calculated, one article [28] was excluded because it did not separately analyze patients with CUP, one article [21] was excluded because fewer than ten patients with CUP were included, one article [23] was 
Table 5 FDG-PET/CT parameters

\begin{tabular}{|c|c|c|c|c|c|c|c|c|}
\hline $\begin{array}{l}\text { Study and } \\
\text { year }\end{array}$ & $\begin{array}{l}\text { Time of fasting } \\
\text { before FDG } \\
\text { administration } \\
\text { (h) }\end{array}$ & $\begin{array}{l}\text { FDG dose } \\
(\mathrm{MBq})\end{array}$ & $\begin{array}{l}\text { Time interval } \\
\text { between FDG } \\
\text { administration } \\
\text { and data } \\
\text { acquisition (min) }\end{array}$ & $\begin{array}{l}\text { No. of CT } \\
\text { detector } \\
\text { rows }\end{array}$ & $\begin{array}{l}\text { Reconstructed } \\
\text { slice width } \\
(\mathrm{mm})\end{array}$ & $\begin{array}{l}\text { Intravenous } \\
\text { CT contrast }\end{array}$ & $\begin{array}{l}\text { Oral CT } \\
\text { contrast }\end{array}$ & $\begin{array}{l}\text { Area of body } \\
\text { scanned }\end{array}$ \\
\hline $\begin{array}{l}\text { Fencl et al. } \\
{[12], 2007}\end{array}$ & $\geq 6$ & $350-450$ & $60-90$ & 2 & 4.0 & Yes and no & Yes & $\begin{array}{l}\text { From the skull } \\
\text { base to below } \\
\text { the groin }\end{array}$ \\
\hline $\begin{array}{l}\text { Nassenstein } \\
\text { et al. [13], } \\
2007\end{array}$ & $\geq 4$ & 350 & 60 & 2 & $\begin{array}{l}-3.0 \text { (head } \\
\text { and neck) } \\
-5.0 \text { (chest } \\
\text { and abdomen) }\end{array}$ & Yes & Yes & $\begin{array}{l}\text { From the head } \\
\text { to the upper } \\
\text { thigh }\end{array}$ \\
\hline $\begin{array}{l}\text { Fleming et al. } \\
{[14], 2007}\end{array}$ & NR & 555 & 75 & 16 & NR & NR & NR & $\begin{array}{l}\text { From the top } \\
\text { of the head } \\
\text { to midthigh }\end{array}$ \\
\hline $\begin{array}{c}\text { Bruna et al. } \\
\text { [15], } 2007\end{array}$ & $\geq 6$ & $\begin{array}{l}5.5 / \mathrm{kg} \\
(\max .550)\end{array}$ & 60 & NR & NR & NR & NR & $\begin{array}{l}\text { From the top } \\
\text { of the head to } \\
\text { midthigh }\end{array}$ \\
\hline $\begin{array}{l}\text { Wartski et al. } \\
{[16], 2007}\end{array}$ & $\geq 6$ & $4-5 / \mathrm{kg}$ & 60 & NR & 5.0 & No & No & $\begin{array}{l}\text { From the skull } \\
\text { to the midthigh }\end{array}$ \\
\hline $\begin{array}{l}\text { Ambrosini } \\
\text { et al. [18], } \\
2006\end{array}$ & 6 & 370 & $60-90$ & NR & NR & NR & NR & "Whole-body" \\
\hline $\begin{array}{l}\text { Fakhry } \\
\text { et al. [20] } \\
2006\end{array}$ & $\geq 6$ & $260-330$ & 60 & NR & NR & NR & NR & $\begin{array}{l}\text { From the skull } \\
\text { base to the } \\
\text { thighs }\end{array}$ \\
\hline $\begin{array}{l}\text { Pelosi et al. } \\
\text { [22], } 2006\end{array}$ & $\geq 6$ & $222-370$ & 60 & NR & NR & NR & NR & $\begin{array}{l}\text { From neck to } \\
\text { pelvis or from } \\
\text { skull to feet }\end{array}$ \\
\hline $\begin{array}{l}\text { Nanni et al. } \\
{[26], 2005}\end{array}$ & $\geq 6$ & 370 & $60-90$ & NR & NR & NR & NR & "Total body scan" \\
\hline $\begin{array}{l}\text { Freudenberg } \\
\text { et al. [27], } \\
2005\end{array}$ & $\geq 10$ & 360 & 60 & 2 & $\begin{array}{l}-3.0 \text { (head } \\
\text { and neck) } \\
-5.0 \text { (from } \\
\text { thorax to } \\
\text { pelvis) }\end{array}$ & $\begin{array}{l}\text {-No (head } \\
\text { and neck } \\
\text {-Yes (thorax } \\
\text { to pelvis) }\end{array}$ & $\begin{array}{l}\text {-No (head } \\
\text { and neck) } \\
\text {-Yes (thorax } \\
\text { to pelvis) }\end{array}$ & $\begin{array}{l}\text { Head, neck, } \\
\text { thorax, } \\
\text { abdomen } \\
\text { and pelvis }\end{array}$ \\
\hline $\begin{array}{l}\text { Gutzeit et al. } \\
\text { [29], } 2005\end{array}$ & $\geq 4$ & 350 & 60 & 2 & 5.0 & Yes & Yes & $\begin{array}{l}\text { Head, neck, } \\
\text { thorax, } \\
\text { abdomen } \\
\text { and pelvis }\end{array}$ \\
\hline
\end{tabular}

CT: computed tomography

FDG: ${ }^{18}$ F-fluoro-2-deoxyglucose

NR: not reported

excluded because it was an editorial, and one article [24] was excluded because the same data were used in a later study. Eventually, 11 studies [12-16, 18, 20, 22, 26, 27, 29], comprising a total sample size of 433 patients with CUP, met all inclusion and exclusion criteria, and they were included in this systematic review. The characteristics of the included studies are presented in Tables 3, 4, 5 and 6 .

\section{Methodological quality assessment}

Twelve methodological quality items were assessed for each of the 11 included studies (Table 7). The total methodological quality score, expressed as a fraction of the maximum score, ranged from $42 \%$ to $75 \%$ (median, $50 \%$ ). 
Table 6 FDG-PET/CT evaluation

\begin{tabular}{|c|c|c|}
\hline Study and year & $\begin{array}{l}\text { Evaluated } \\
\text { images }\end{array}$ & $\begin{array}{l}\text { Interpreter(s) of } \\
\text { FDG-PET/CT }\end{array}$ \\
\hline $\begin{array}{r}\text { Fencl et al. } \\
{[12], 2007}\end{array}$ & $\mathrm{AC}$ and $\mathrm{nAC}$ & $\begin{array}{l}\text { Seven physicians experienced } \\
\text { in both PET and CT reading } \\
\text { were randomly involved in } \\
\text { routine evaluation of findings; } \\
\text { in the event of any uncertainty, } \\
\text { a second or even a third } \\
\text { opinion was solicited }\end{array}$ \\
\hline
\end{tabular}

\begin{tabular}{|c|c|c|}
\hline $\begin{array}{l}\text { Nassenstein } \\
\text { et al. [13], } \\
2007\end{array}$ & NR & $\begin{array}{l}\text { Two different reading tean } \\
\text { each consisting of a radio } \\
\text { and a nuclear medicine } \mathrm{pl}\end{array}$ \\
\hline $\begin{array}{l}\text { Fleming } \\
\text { et al. [14], } \\
2007\end{array}$ & NR & One of three neuroradiolo \\
\hline $\begin{array}{l}\text { Bruna et al. } \\
\text { [15], } 2007\end{array}$ & NR & NR \\
\hline $\begin{array}{l}\text { Wartski } \\
\text { et al. [16], } \\
2007\end{array}$ & $\mathrm{AC}$ and $\mathrm{nAC}$ & $\begin{array}{l}\text { Two experienced nuclear } \\
\text { medicine physicians, } \\
\text { independently }\end{array}$ \\
\hline
\end{tabular}

Ambrosini

et al. [18], 2006

Fakhry et al. NR [20] 2006

Two nuclear medicine physicians

Criteria for positivity

Reference standard

FDG hypermetabolism at the site of pathological changes on CT or marked focal hypermetabolism at sites suggestive of malignancy (liver parenchyma, bone marrow) despite absence of signs of pathology at those sites on $\mathrm{CT}$
A diagnosis of the primary site of a malignancy was classified as true positive only when it was confirmed histologically. If the finding was not confirmed histologically, the diagnosis was classified as false positive. An evaluation was classified as true negative if neither FDG-PET/CT nor histological findings or clinical follow-up (including subsequent imaging tests) determined the site of the primary. When the site of the primary was not identified, but was proven histologically, the finding was classified as false negative

"Full medical history was available for all patients"

Contrast-enhancing mass CT or focally increased FDG uptake on PET

An SUV level greater than 2.5 Each site of increased PET metabolic was considered consistent with activity was compared with operative abnormal, hypermetabolic activity in primary, regional and distant disease

NR

Increased FDG focal uptake indicative of a primary tumor in the head and neck and/or chest regions

NR physicians in consensus histopathology records

FDG-PET/CT results were correlated to the patient's medical record concerning pathological results and treatment. A FDG-PET/CT result was considered as a true positive when an FDG focus matched the primary tumor found during the second panendoscopy, a false positive when the increased FDG focal uptake did not match panendoscopy results and a false negative when the second panendoscopy detected malignant lesions with no corresponding increased FDG focal uptake -PET/CT findings were subsequently confirmed by surgery or biopsy of the primary tumor -Gastroscopy and 3-month follow-up in one patient Histology and/or clinical follow-up $>6$ months in all patients

\author{
-"Follow-up" \\ -Histology (n=7) \\ -Complimentary examination $(\mathrm{n}=3)$, \\ among which were CT of the \\ abdomen and pelvis $(n=2)$
}


Table 6 (continued)

\begin{tabular}{|c|c|c|c|c|}
\hline Study and year & $\begin{array}{l}\text { Evaluated } \\
\text { images }\end{array}$ & $\begin{array}{l}\text { Interpreter(s) of } \\
\text { FDG-PET/CT }\end{array}$ & Criteria for positivity & Reference standard \\
\hline $\begin{array}{l}\text { Pelosi et al. } \\
{[22], 2006}\end{array}$ & NR & $\begin{array}{l}\text { Two nuclear medicine } \\
\text { physicians in consensus }\end{array}$ & NR & $\begin{array}{l}\text { The FDG pathological findings, } \\
\text { suspected for primaries, were further } \\
\text { investigated with other imaging } \\
\text { examination, biopsy and/or surgery } \\
\text { and clinical follow-up (minimum } \\
\text { follow-up of } 3 \text { months after the } \\
\text { FDG-PET/CT study) }\end{array}$ \\
\hline $\begin{array}{l}\text { Nanni et al. } \\
\text { [26], } 2005\end{array}$ & NR & $\begin{array}{l}\text { Three skilled nuclear } \\
\text { medicine physicians; in } \\
\text { case of discrepancy, the } \\
\text { FDG-PET/CT interpretation } \\
\text { was reached by consensus }\end{array}$ & NR & $\begin{array}{l}\text {-FDG-PET/CT findings were } \\
\text { subsequently confirmed by surgery } \\
\text { or biopsy of the primary tumor } \\
\text {-Gastroscopy in one patient }\end{array}$ \\
\hline $\begin{array}{l}\text { Freudenberg } \\
\text { et al. [27], } \\
2005\end{array}$ & NR & $\begin{array}{l}\text { Two experienced nuclear } \\
\text { medicine physicians in } \\
\text { consensus (FDG-PET) } \\
\text { and two radiologists (CT) }\end{array}$ & $\begin{array}{l}\text {-FDG-PET: regions of focally } \\
\text { increased tracer uptake (a } \\
\text { maximum SUV of }>2.5 \text { was } \\
\text { considered to represent } \\
\text { malignancy in otherwise } \\
\text { equivocal findings) } \\
\text {-CT: contrast-enhancing } \\
\text { masses or asymmetries } \\
\text { typical of malignancies }\end{array}$ & $\begin{array}{l}\text { Histopathology }(n=14) \text { and clinical } \\
\text { follow-up } \geq 9 \text { months }(n=7) \text { with } \\
\text { subsequent panendoscopy with biopsy } \\
\text { of the most probable tumor sites } \\
(n=7) \text {, ultrasound }(n=7), \text { CT }(n=6) \text {, } \\
\text { MRI }(n=6) \text {, diagnostic tonsillectomy } \\
(n=4) \text { and additional biopsies }(n=4)\end{array}$ \\
\hline $\begin{array}{l}\text { Gutzeit et al. } \\
\text { [29], } 2005\end{array}$ & $\mathrm{AC}$ and $\mathrm{nAC}$ & $\begin{array}{l}\text { A nuclear medicine } \\
\text { physician and a radiologist, } \\
\text { both with } 2 \text { years of } \\
\text { PET/CT experience }\end{array}$ & $\begin{array}{l}\text { Contrast material-enhanced } \\
\text { mass on CT or focally } \\
\text { increased glucose metabolism } \\
\text { with a SUV exceeding } \\
2.5 \text { on FDG-PET }\end{array}$ & $\begin{array}{l}\text {-All potential sites of the primary } \\
\text { tumor depicted by FDG-PET/CT were } \\
\text { histologically verified } \\
\text {-Axillary lymph node dissection in one } \\
\text { FDG-PET/CT-negative patient } \\
\text {-Endoscopy and biopsy of the } \\
\text { esophagus in one FDG-PET/CT- } \\
\text { negative patient }\end{array}$ \\
\hline
\end{tabular}

AC: attenuation-corrected images

nAC: non-attenuation-corrected images

CT: computed tomography

FDG-PET: ${ }^{18}$ F-fluoro-2-deoxyglucose positron emission tomography

FDG-PET/CT: ${ }^{18}$ F-fluoro-2-deoxyglucose positron emission tomography/computed tomography

PET: positron emission tomography

PET/CT: positron emission tomography/computed tomography

NR: not reported

SUV: standardized uptake value

\section{Diagnostic performance}

The results of the 11 included studies are presented in Tables 8 and 9, and Figs. 1, 2 and 3. Primary tumor detection rates ranged from 22 to $73 \%$, with an overall detection rate of $37 \%(162 / 433)$ (Table 8). The most commonly detected location of the primary tumor by FDG$\mathrm{PET} / \mathrm{CT}$ was the lung, 33\% (Fig. 1). The most common locations of false-positive FDG-PET/CT findings were the lung and the oropharynx, both $15 \%$ (Fig. 2). The most common cause of false-negative FDG-PET/CT findings was breast cancer, $27 \%$ (Fig. 3). Sensitivity and specificity of FDG-PET/CT in primary tumor detection ranged from $55 \%$ to $100 \%$ and from $73 \%$ to $100 \%$, with pooled estimates of $84 \%$ (95\% CI 78-88\%) and $84 \%$ (95\% CI 78$89 \%$ ), respectively (Table 8 ). The included studies were statistically heterogeneous in their estimates of sensitivity $(P=0.0001)$, but homogeneous in their estimates of specificity $(P=0.2114)$.

A Spearman correlation coefficient of $-0.201 \quad(P=$ $0.554)$ between the logit of sensitivity and logit of 1specificity did not suggest the presence of a threshold effect. No significantly increased RDORs were observed in any of the subgroup analyses according to 
Table 7 Quality assessment of the 11 included studies

\begin{tabular}{|c|c|c|c|c|c|c|c|c|c|c|c|c|c|}
\hline \multirow[t]{2}{*}{ Study and year } & \multicolumn{12}{|c|}{ Quality items } & \multirow[t]{2}{*}{$\%$ of maximum score } \\
\hline & 1 & 2 & 3 & 4 & 5 & 6 & 7 & 8 & 9 & 10 & 11 & 12 & \\
\hline Fencl et al. [12], 2007 & - & + & + & + & + & + & - & - & - & + & + & + & 67 \\
\hline Nassenstein et al. [13], 2007 & - & - & - & + & - & + & - & - & - & + & + & + & 42 \\
\hline Fleming et al. [14], 2007 & - & + & - & - & + & - & - & - & - & + & + & + & 42 \\
\hline Bruna et al. [15], 2007 & - & + & + & + & - & - & - & - & - & + & + & + & 50 \\
\hline Wartski et al. [16], 2007 & - & - & - & + & + & + & + & + & - & + & + & + & 67 \\
\hline Ambrosini et al. [18], 2006 & - & - & - & - & - & - & + & - & + & + & + & + & 42 \\
\hline Fakhry et al. [20] 2006 & - & + & + & + & - & - & - & - & - & + & + & + & 50 \\
\hline Pelosi et al. [22], 2006 & + & - & + & + & - & - & - & - & - & + & + & + & 50 \\
\hline Nanni et al. [26], 2005 & + & - & + & - & + & - & + & + & + & + & + & + & 75 \\
\hline Freudenberg et al. [27], 2005 & - & - & + & + & + & + & + & - & - & + & + & + & 67 \\
\hline Gutzeit et al. [29], 2005 & - & - & - & - & + & + & + & + & - & + & + & + & 58 \\
\hline
\end{tabular}

completeness of diagnostic workup before FDG-PET/ $\mathrm{CT}$, location of metastases of unknown primary, administration of CT contrast agents, type of FDG$\mathrm{PET} / \mathrm{CT}$ images evaluated and way of FDG-PET/CT review (Table 9).

\section{Discussion}

CUP represents a heterogeneous group of metastatic tumors for which no primary site can be detected following a thorough medical history, careful clinical examination and extensive diagnostic workup [1, 2]. Attempts to identify the primary tumor in patients with CUP are are often time consuming, expensive and ultimately unsuccessful $[1,2]$. The results of this study indicate that, overall, FDG-PET/CT is able to detect $37 \%$ of primary tumors in patients with CUP, and sensitivity and specificity are reasonably high (both 84\%). Sensitivity, however, was heterogeneous across studies. Subgroup analysis could not clarify the observed heterogeneity. It should be noted, however, that results from our subgroup analysis may not be conclusive because of the relatively small number of included studies. Furthermore, it was not possible to perform subgroup analysis according to the number of CT detector rows and CT slice width due to incomplete reporting of included studies. Future studies are required to further investigate potential sources of heterogeneity.

The results of this systematic review should be interpreted carefully, since the methodological quality of the included studies was moderate. Several methodological shortcomings were identified, of which spectrum bias, bias due to the use of an inadequate reference standard and verification bias may seriously have affected the results. According to Pavlidis et al. [1,2], the precise clinical definition of CUP should refer to patients who present with histologically confirmed metastatic cancer in whom medical history, physical examination, full blood count, basic

Table 8 Diagnostic performance of FDG-PET/CT in primary tumor detection

\begin{tabular}{llllll}
\hline Study and year & Primary tumor detection rate (\%) & \multicolumn{2}{c}{ Sensitivity (\%) } & \multicolumn{2}{c}{ Specificity (\%) } \\
\cline { 4 - 5 } & & Value & $95 \%$ CI & Value & $95 \%$ CI \\
\hline Fencl et al. [12], 2007 & 22 & 55 & $38-70$ & 75 \\
Nassenstein et al. [13], 2007 & 28 & 100 & $74-100$ & 85 & $62-85$ \\
Fleming et al. [14], 2007 & 73 & 94 & $73-99$ & 100 & $61-100$ \\
Bruna et al. [15], 2007 & 38 & 93 & $70-99$ & 77 & $57-90$ \\
Wartski et al. [16], 2007 & 34 & 93 & $69-99$ & 73 & $48-89$ \\
Ambrosini et al. [18], 2006 & 53 & 100 & $84-100$ & 95 & $76-99$ \\
Fakhry et al. [20] 2006 & 32 & 70 & $40-89$ & 75 & $47-91$ \\
Pelosi et al. [22], 2006 & 35 & 83 & $66-93$ & 87 & $73-94$ \\
Nanni et al. [26], 2005 & 57 & 100 & $76-100$ & 89 & $57-98$ \\
Freudenberg et al. [27], 2005 & 57 & 86 & $60-96$ & 100 & $65-100$ \\
Gutzeit et al. [29], 2005 & 33 & 88 & $66-97$ & 89 & $73-96$ \\
Pooled estimate & 37 & 84 & $78-88$ & 84 & $78-89$
\end{tabular}


Table 9 Results of subgroup analysis

\begin{tabular}{|c|c|c|c|c|c|}
\hline \multirow[t]{2}{*}{ Parameter } & \multirow[t]{2}{*}{ Value } & \multirow[t]{2}{*}{ No. of studies } & \multicolumn{3}{|c|}{ Relative diagnostic odds ratio (1 vs. 2 ) } \\
\hline & & & Value & $95 \% \mathrm{CI}$ & P-value \\
\hline \multirow[t]{2}{*}{ Completeness of diagnostic workup before FDG-PET/CT } & 1. Complete & 2 & 1.93 & $0.22-17.28$ & 0.5072 \\
\hline & 2. Incomplete & 9 & & & \\
\hline \multirow[t]{2}{*}{ Location of metastases } & 1. Cervical & 6 & 0.38 & $0.02-9.55$ & 0.4765 \\
\hline & 2. Extracervical & 2 & & & \\
\hline \multirow[t]{2}{*}{ Administration of $\mathrm{CT}$ contrast agents } & 1. Intravenous and oral & 3 & 2.42 & $0.32-18.15$ & 0.3347 \\
\hline & 2. Not reported & 7 & & & \\
\hline \multirow[t]{2}{*}{ Evaluated FDG-PET/CT images } & 1. $\mathrm{AC}$ and $\mathrm{nAC}$ & 3 & 0.36 & $0.06-2.09$ & 0.2187 \\
\hline & 2. AC only or NR & 8 & & & \\
\hline \multirow[t]{2}{*}{ Way of FDG-PET/CT review } & 1. Reported blinding & 3 & 1.18 & $0.10-13.54$ & 0.8766 \\
\hline & 2. No reported blinding & 8 & & & \\
\hline
\end{tabular}

AC: attenuation-corrected images

nAC: non-attenuation-corrected images

NR: not reported

biochemistry battery, urinalysis, stool occult blood testing, immunohistochemistry with specific markers as well as imaging technology with chest X-ray, CT of the chest abdomen and pelvis or mammography and MR imaging in certain cases have failed to detect the primary tumor. However, only two studies $[22,26](18 \%)$ included patients who fulfilled these criteria. In the other nine studies [12-16, 18, 20, 27, 29], diagnostic performance of FDG-PET/CT might have been overestimated because of (possible) incomplete diagnostic workup. Furthermore, only five studies $[12,15,20,22,27]$ applied an adequate

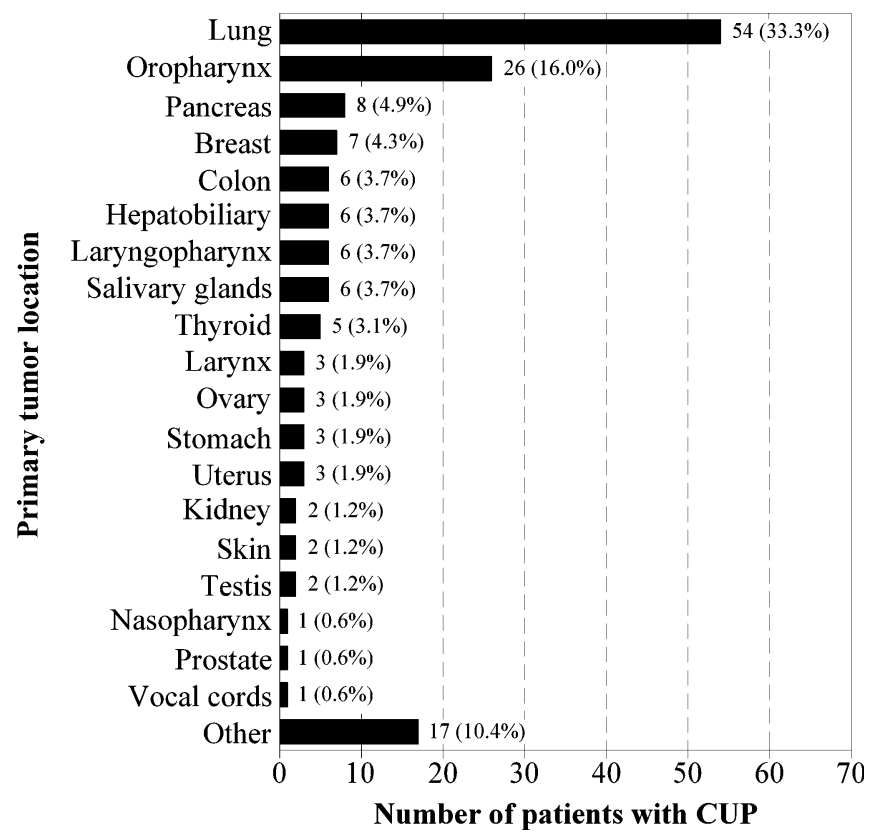

Fig. 1 Locations of primary tumours detected by FDG-PET/CT reference standard of histology and follow-up in all patients. Consequently, in the other six studies [13, 14 , $16,18,26,29]$, diagnostic performance of FDG-PET/CT might have been overestimated. Other methodological flaws include an inadequate description of selection criteria in seven studies $[13,16,18,22,26,27,29](64 \%)$, the possibility that FDG-PET/CT formed part of the reference standard (incorporation bias) in five studies $[13,15,18,20$, 22] (46\%), inadequate description of the execution of FDG-PET/CT in six studies $[14,15,18,20,22,26](55 \%)$, inadequate description of the reference standard in six studies $[12-15,20,22](55 \%)$, possible interpretation of FDG-PET/CT while knowing the results of the reference standard (test review bias) in eight studies $[12-15,18,20$, $22,27](73 \%)$ and possible interpretation of FDG-PET/CT without knowledge of the histological nature of the metastases of unknown primary in nine studies [12-15, $16,20,22,27,29](82 \%)$.

Lung, oropharyngeal and pancreatic carcinoma were the most frequently detected primary tumors by FDG-PET/CT

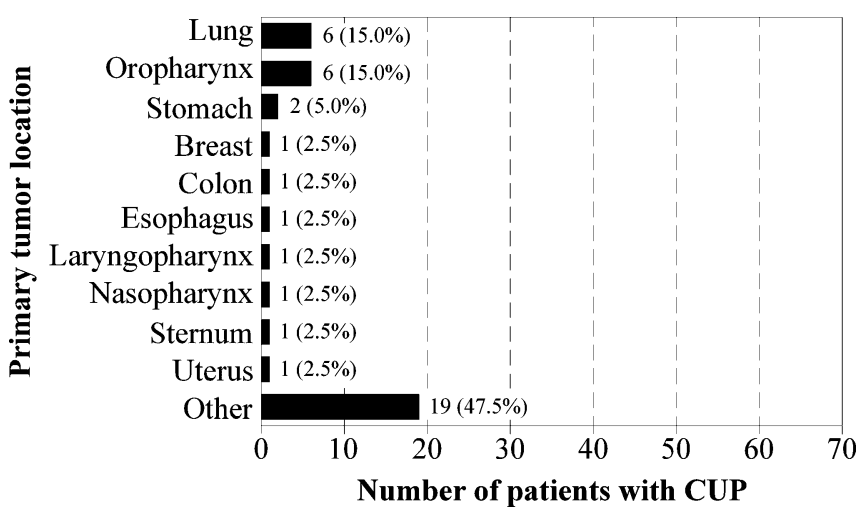

Fig. 2 Locations of false-positive FDG-PET/CT findings 


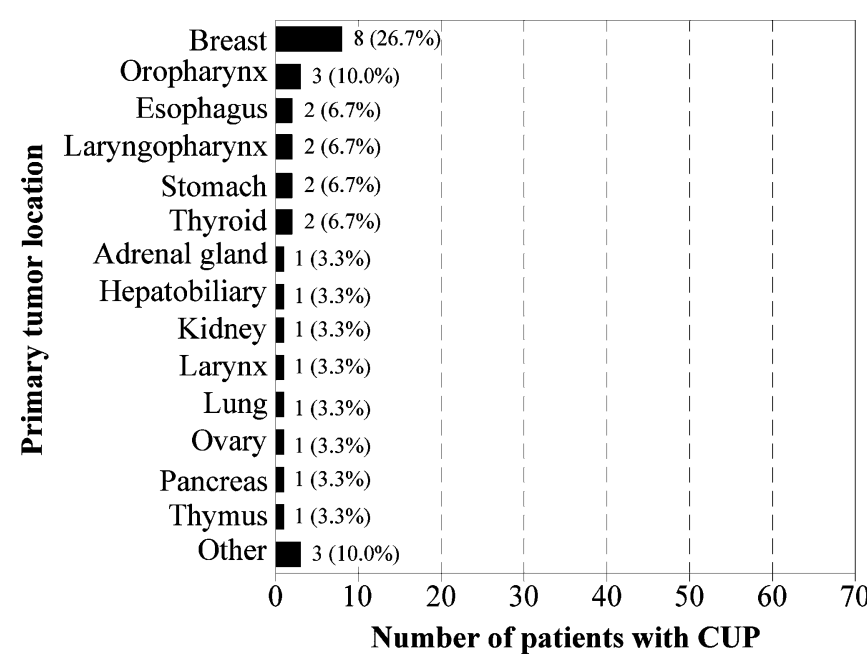

Fig. 3 Locations of false-negative FDG-PET/CT findings

in this meta-analysis $(33 \%, 16 \%$ and $5 \%$, respectively). This is partly in line with previous autopsy studies in patients with CUP [31-34], which have shown that the most common locations of the primary tumor are the lung and the pancreas. The high detection rate of oropharyngeal carcinoma by FDG-PET/CT in this meta-analysis, however, is discrepant with the results of autopsy studies [31-34]. This finding can by explained by the fact that 4 of 11 included studies $[13,16,20,27]$ exclusively investigated patients with cervical metastases of unknown primary, whose primary tumors are most frequently located in the oropharynx [5, 35]. Indeed, these four studies [13, 16, 20, 27] comprised $69 \%$ of all oropharyngeal carcinomas detected by FDG-PET/CT in this meta-analysis. The most commonly reported locations of false-positive FDGPET/CT results were the lung and the oropharynx (both $15 \%$ ). Causes of false-positive results may be FDG uptake in benign conditions with increased glycolysis (e.g., one false-positive FDG-PET/CT finding in the lung proved to be a pulmonary infarction [29]), high physiological FDG uptake (e.g., muscle FDG uptake) and failure to evaluate both attenuation-corrected and non-attentuation-corrected images to minimize the chance of misinterpreting (FDGPET/CT) artifacts as pathologic (only three of the included studies $[12,16,29]$ explicitly stated that both attenuationcorrected and non-attentuation-corrected images were evaluated) [36-38]. Breast cancer was the most common cause of false-negative FDG-PET/CT results (27\%). This may be explained by the fact that small $(<1 \mathrm{~cm})$ and slowgrowing, low-grade (breast) cancers with low or no FDG uptake (e.g., tubular carcinoma and noninvasive cancers such as ductal or lobular carcinoma in situ) may be overlooked on FDG-PET/CT [39].

FDG-PET alone has been thoroughly investigated for primary tumor detection in patients with CUP; metaanalyses on FDG-PET reported primary tumor detection rates ranging between $24.5 \%$ and $43 \%$, sensitivities ranging between $87 \%$ and $91.9 \%$, and specificities ranging between $71 \%$ and $81.9 \%$ [4-6]. An advantage of FDG$\mathrm{PET} / \mathrm{CT}$ over FDG-PET alone is more accurate localization of foci with increased FDG uptake, and this may reduce the problems of physiological FDG uptake being misinterpreted as pathological and false localization of disease. In addition, tumors with low or no FDG uptake, or tumors of a size below the spatial resolution of FDG-PET, may be depicted by the CT component of FDG-PET/CT. Recently introduced combined FDG-PET/CT scanners with a 64section multidetector CT component and less than $2.5-\mathrm{mm}$ collimation may detect small primary cancers in the lungs or oropharynx earlier [40] and are clearly superior to FDG$\mathrm{PET} / \mathrm{CT}$ alone. Furthermore, the additional anatomic data obtained using FDG-PET/CT may increase the accuracy of FDG-PET-directed biopsies. Another advantage of FDG$\mathrm{PET} / \mathrm{CT}$ is the use of the CT images for attenuation correction of the PET emission data, which reduces wholebody scanning times from $45 \mathrm{~min}$ to $30 \mathrm{~min}$ or less. This approach also provides low-noise attenuation correction factors, compared with those from standard PET transmission measurements using an external radiation source, and eliminates bias from emission contamination of postinjection transmission scans $[7,8]$. On the other hand, a disadvantage of CT-based attenuation correction may be misclassification of regions containing high concentrations of CT contrast medium with high-density bone (CT contrast agents have high atomic numbers relative to the atomic number of bone, and as the concentration of a contrast agent increases, its corresponding CT number will fall within the CT number range for bone), which results in overcorrection for photon attenuation, consequently leading to an overestimation of FDG uptake in the contrastenhanced region $[41,42]$. Three of the included studies [13, 27, 29] directly compared FDG-PET/CT and (CT-based attenuation-corrected) FDG-PET alone. In all three studies $[13,27,29]$, FDG-PET/CT was able to detect a few more primary tumors than FDG-PET alone, but these differences were not statistically significant. Therefore, FDG$\mathrm{PET} / \mathrm{CT}$ has not yet been proven to be diagnostically superior to FDG-PET alone. More studies directly comparing FDG-PET/CT and FDG-PET alone are required to prove the assumed advantage of FDG-PET/CT over FDG-PET alone.

Whole-body MR imaging may be an alternative to FDG$\mathrm{PET} / \mathrm{CT}$ [43]; it does not require the operator to work with a potentially harmful radiotracer, the safety profile of MR contrast agents is favorable compared with that of iodinated contrast with CT [44], and the costs for a whole-body MR imaging examination (about 575 euros) are approximately two times less than that of a whole-body FDG-PET/CT examination (about 1,123 euros) [45]. In 1998, Eustace et al. [46] showed the potential of whole-body MR imaging in primary tumor detection in four patients with CUP, using a short-tau-inversion-recovery sequence. However, to our knowledge, no other reports on the diagnostic performance 
of whole-body MR imaging in unknown primary tumor detection have been published since then, while (both anatomical and functional whole-body) MR technology has continued to evolve $[47,48]$.

Identification of the primary tumor in patients with CUP enables accurate tumor staging, which allows optimizing treatment planning; this, in turn, may improve patient prognosis. On the other hand, it should be realized that FDG-PET/CT is an expensive examination, and falsepositive FDG-PET/CT findings may result in unnecessary additional invasive diagnostic procedures, which have associated morbidities and costs [49]. In general, it appears that patients with CUP have a limited life expectancy, with a median survival of approximately $6-9$ months $[1,2]$, but a median survival of 23 months has been reported for patients with CUP and an identified primary tumor subsequently treated with specific therapy [50]. Similarly, one study [51] reported that the 3-year survival rate for patients with cervical metastases and occult oropharyngeal primary tumors was $100 \%$ after treatment, while the patients with cervical metastases in which a primary tumor was not detected showed a survival rate of $58 \%$. Only four studies included in this systematic review reported the therapeutic impact of FDG-PET/CT; in these four studies,
FDG-PET/CT modified therapy in $18.2-60 \%$ of patients $[15,16,20,22]$. Although one study [12] reported that the survival rate of CUP patients with at least one hypermetabolic lesion was significantly lower $(P<0.0279)$ than that of the remaining CUP patients, none of the included studies reported FDG-PET/CT-modified patient outcomes. Therefore, the additional value of FDG-PET/CT to patients with CUP and its cost-effectiveness should be further investigated; the currently presented data can be used to perform such an analysis.

In conclusion, although included studies were of moderate methodological quality and their results were heterogeneous, the results of this systematic review and meta-analysis indicate that FDG-PET/CT can be a useful method for unknown primary tumor detection. Future studies are required to prove the assumed advantage of FDG-PET/CT over FDG-PET alone and to further explore causes of heterogeneity.

Open Access This article is distributed under the terms of the Creative Commons Attribution Noncommercial License which permits any noncommercial use, distribution, and reproduction in any medium, provided the original author(s) and source are credited.

\section{References}

1. Pavlidis N (2007) Forty years experience of treating cancer of unknown primary. Acta Oncol 46:592-601

2. Pavlidis N, Briasoulis E, Hainsworth J, Greco FA (2003) Diagnostic and therapeutic management of cancer of an unknown primary. Eur J Cancer 39:1990-2005

3. Rohren EM, Turkington TG, Coleman RE (2004) Clinical applications of PET in oncology. Radiology 231:305-332

4. Sève P, Billotey C, Broussolle C, Dumontet C, Mackey JR (2007) The role of 2-deoxy-2-[F-18]fluoro-D-glucose positron emission tomography in disseminated carcinoma of unknown primary site. Cancer 109:292-299

5. Rusthoven KE, Koshy M, Paulino AC (2004) The role of fluorodeoxyglucose positron emission tomography in cervical lymph node metastases from an unknown primary tumor. Cancer 101:2641-2649

6. Delgado-Bolton RC, Fernández-Pérez C, González-Maté A, Carreras JL (2003) Meta-analysis of the performance of $18 \mathrm{~F}-\mathrm{FDG}$ PET in primary tumor detection in unknown primary tumors. J Nucl Med 44:1301-1314
7. Blodgett TM, Meltzer CC, Townsend DW (2007) PET/CT: form and function. Radiology 242:360-385

8. Von Schulthess GK, Steinert HC, Hany TF (2006) Integrated PET/CT: current applications and future directions. Radiology 238:405-422

9. Whiting P, Rutjes AW, Reitsma JB, Bossuyt PM, Kleijnen J (2003) The development of QUADAS: a tool for the quality assessment of studies of diagnostic accuracy included in systematic reviews. BMC Med Res Methodol 3:25

10. Whiting PF, Weswood ME, Rutjes AW, Reitsma JB, Bossuyt PN, Kleijnen J (2006) Evaluation of QUADAS, a tool for the quality assessment of diagnostic accuracy studies. BMC Med Res Methodol 6:9

11. Zamora J, Abraira V, Muriel A, Khan K, Coomarasamy A (2006) Meta-DiSc: a software for meta-analysis of test accuracy data. BMC Med Res Methodol 6:31

12. Fencl P, Belohlavek O, Skopalova M, Jaruskova M, Kantorova I, Simonova K (2007) Prognostic and diagnostic accuracy of [18F]FDG-PET/CT in 190 patients with carcinoma of unknown primary. Eur J Nucl Med Mol Imaging 34:1783-1792
13. Nassenstein K, Veit-Haibach P, Stergar $\mathrm{H}$ et al (2007) Cervical lymph node metastases of unknown origin: primary tumor detection with whole-body positron emission tomography/computed tomography. Acta Radiol 23:1-8

14. Fleming AJ Jr, Smith SP Jr, Paul CM et al (2007) Impact of [18F]-2-fluorodeoxyglucose-positron emission tomography/ computed tomography on previously untreated head and neck cancer patients. Laryngoscope 117:1173-1179

15. Bruna C, Journo A, Netter F et al (2007) On the interest of PET with 18FFDG in the management of cancer of unknown primary (CUP). Med Nucl 31:242-249

16. Wartski M, Le Stanc E, Gontier E et al (2007) In search of an unknown primary tumor presenting with cervical metastases: performance of hybrid FDG-PET-CT. Nucl Med Commun 28:365-371

17. Paul SA, Stoeckli SJ, von Schulthess GK, Goerres GW (2007) FDG PET and $\mathrm{PET} / \mathrm{CT}$ for the detection of the primary tumor in patients with cervical non-squamous cell carcinoma metastasis of an unknown primary. Eur Arch Otorhinolaryngol 264:189-195 
18. Ambrosini V, Nanni C, Rubello D et al (2006) 18F-FDG PET/CT in the assessment of carcinoma of unknown primary origin. Radiol Med (Torino) 111:1146-1155

19. Schneider K, Hrasky A, Aschoff P, Bihl $H$, Hagen R (2006) Significance of PET and integrated PET/CT in the diagnostics of occult primary tumors. Laryngorhinootologie 85:819-823

20. Fakhry N, Barberet M, Lussato D et al (2006) Role of [18F]-FDG PET-CT in the management of the head and neck cancers. Bull Cancer 93:1017-1025

21. Schneider K, Aschoff P, Bihl H, Hagen $R$ (2006) The integrated PET/CT: technological advance in diagnostics of head and neck recurrencies and CUP? Laryngorhinootologie 85:179-183

22. Pelosi E, Pennone M, Deandreis D, Douroukas A, Mancini M, Bisi G (2006) Role of whole body positron emission tomography/computed tomography scan with 18 F-fluorodeoxyglucose in patients with biopsy proven tumor metastases from unknown primary site. Q J Nucl Med Mol Imaging 50:15-22

23. Maldonado A, Gonzalez Alenda J (2006) The anatomicometabolic PET$\mathrm{CT}$ in carcinoma of unknown primary site. Oncologia (Spain) 29:93-94

24. Fakhry N, Jacob T, Paris J et al (2006) Contribution of 18-F-FDG PET for detection of head and neck carcinomas with an unknown primary tumor. Ann Otolaryngol Chir Cervicofac 123:1725

25. Zanation AM, Sutton DK, Couch ME, Weissler MC, Shockley WW, Shores CG (2005) Use, accuracy, and implications for patient management of [18F]-2-fluorodeoxyglucose-positron emission/computerized tomography for head and neck tumors. Laryngoscope 115:1186-1190

26. Nanni C, Rubello D, Castellucci P et al (2005) Role of 18F-FDG PET-CT imaging for the detection of an unknown primary tumor: preliminary results in 21 patients. Eur J Nucl Med Mol Imaging 32:589-592

27. Freudenberg LS, Fischer M, Antoch G et al (2005) Dual modality of $18 \mathrm{~F}$ fluorodeoxyglucose-positron emission tomography/computed tomography in patients with cervical carcinoma of unknown primary. Med Princ Pract 14:155-160
28. Syed R, Bomanji JB, Nagabhushan N et al (2005) Impact of combined (18)FFDG PET/CT in head and neck tumors. Br J Cancer 92:1046-1050

29. Gutzeit A, Antoch G, Kühl H et al (2005) Unknown primary tumors: detection with dual-modality PET/CT initial experience. Radiology 234:227234

30. Rödel R, Straehler-Pohl HJ, Palmedo H et al (2004) PET/CT imaging in head and neck tumors. Radiologe 44:10551059

31. Blaszyk H, Hartmann A, Bjornsson J (2007) Cancer of unknown primary origin: a decade of experience in a community-based hospital. Am J Surg 194:833-837

32. Al-Brahim N, Ross C, Carter B, Chorneyko K (2005) The value of postmortem examination in cases of metastasis of unknown origin-20-year retrospective data from a tertiary care center. Ann Diagn Pathol 9:77-80

33. Mayordomo JI, Guerra JM, Guijarro C et al (1993) Neoplasms of unknown primary site: a clinicopathological study of autopsied patients. tumori 79:321-324

34. Le Chevalier T, Cvitkovic E, Caille P et al (1988) Early metastatic cancer of unknown primary origin at presentation. A clinical study of 302 consecutive autopsied patients. Arch Intern Med 148:2035-2039

35. Werner JA, Dünne AA, Myers JN (2003) Functional anatomy of the lymphatic drainage system of the upper aerodigestive tract and its role in metastasis of squamous cell carcinoma. Head Neck 25:322-332

36. Mawlawi O, Pan T, Macapinlac HA (2006) PET/CT imaging techniques, considerations, and artifacts. J Thorac Imaging 21:99-110

37. Truong MT, Pan T, Erasmus JJ (2006) Pitfalls in integrated CT-PET of the thorax: implications in oncologic imaging. J Thorac Imaging 21:111-122

38. Blodgett TM, Fukui MB, Snyderman $\mathrm{CH}$ et al (2005) Combined PET-CT in the head and neck: part 1. Physiologic, altered physiologic, and artifactual FDG uptake. Radiographics 25:897912

39. Lim HS, Yoon W, Chung TW et al (2007) FDG PET/CT for the detection and evaluation of breast diseases: usefulness and limitations. Radiographics 27(suppl 1):S197-S213

40. Fischbach F, Knollmann F, Griesshaber V, Freund T, Akkol E, Felix R (2003) Detection of pulmonary nodules by multislice computed tomography: improved detection rate with reduced slice thickness. Eur Radiol 13:2378-2383
41. Ay MR, Zaidi H (2006) Assessment of errors caused by X-ray scatter and use of contrast medium when using CT-based attenuation correction in PET. Eur J Nucl Med Mol Imaging 33:1301-1313

42. Antoch G, Freudenberg LS, Egelhof T et al (2002) Focal tracer uptake: a potential artifact in contrast-enhanced dual-modality PET/CT scans. J Nucl Med 43:1339-1342

43. Lauenstein TC, Semelka RC (2006) Emerging techniques: whole-body screening and staging with MRI. J Magn Reson Imaging 24:489-498

44. Runge VM (2001) Safety of magnetic resonance contrast media. Top Magn Reson Imaging 12:309-314

45. Plathow C, Walz M, Lichy MP et al (2008) Cost considerations for wholebody MRI and PET/CT as part of oncologic staging. Radiologe 48:384396

46. Eustace S, Tello R, DeCarvalho V, Carey J, Melhem E, Yucel EK (1998) Whole body turbo STIR MRI in unknown primary tumor detection. J Magn Reson Imaging 8:751753

47. Brauck K, Zenge MO, Vogt FM et al (2008) Feasibility of whole-body MR with T2- and T1-weighted real-time steady-state free precession sequences during continuous table movement to depict metastases. Radiology 246:910 916

48. Kwee TC, Takahara T, Ochiai R, Nievelstein RAJ, Luijten PR (2008) Diffusion-weighted whole-body imaging with background body signal suppression (DWIBS): features and potential applications in oncology. Eur Radiol 18:1937-1952

49. Schapira DV, Jarrett AR (1995) The need to consider survival, outcome, and expense when evaluating and treating patients with unknown primary carcinoma. Arch Intern Med 155:2050 2054

50. Raber MN, Faintuch J, Abbruzzese JL, Sumrall C, Frost P (1991) Continuous infusion 5-fluorouracil, etoposide and cis-diamminedichloroplatinum in patients with metastatic carcinoma of unknown primary origin. Ann Oncol 2:519-520

51. Haas I, Hoffmann TK, Engers R, Ganzer U (2002) Diagnostic strategies in cervical carcinoma of an unknown primary (CUP). Eur Arch Otorhinolaryngol 259:325-333 